\title{
Article \\ Improvement of Mechanical, Tribological, and Fricative Reduction Properties of Pure Titanium by Boriding
}

\author{
Tong Chen ${ }^{1, *(\mathbb{D})}$, Shinji Koyama ${ }^{1}$ and Lihua $\mathrm{Yu}^{2}$ \\ 1 Mechanical Science and Technology, Graduate School of Science and Technology, Gunma University, \\ Gunma 371-8510, Japan; koyama@gunma-u.ac.jp \\ 2 School of Material Science and Engineering, Jiangsu University of Science and Technology, \\ Zhenjiang 212003, China; lhyu6@just.edu.cn \\ * Correspondence: t182b602@gunma-u.ac.jp; Tel.: +81-27-730-1659
}

Citation: Chen, T.; Koyama, S.; Yu, L. Improvement of Mechanical, Tribological, and Fricative Reduction Properties of Pure Titanium by Boriding. Appl. Sci. 2021, 11, 4862. https://doi.org/10.3390/app11114862

Academic Editor: David G. Calatayud

Received: 7 May 2021

Accepted: 24 May 2021

Published: 25 May 2021

Publisher's Note: MDPI stays neutra with regard to jurisdictional claims in published maps and institutional affiliations.

Copyright: (c) 2021 by the authors. Licensee MDPI, Basel, Switzerland. This article is an open access article distributed under the terms and conditions of the Creative Commons Attribution (CC BY) license (https:// creativecommons.org/licenses/by/ $4.0 /)$.

\begin{abstract}
Surface boriding of pure titanium was performed using dissolved salt impregnation to modify the surface hardness and improve wear performance. The effect of boriding temperature (950-1150 ${ }^{\circ} \mathrm{C}$ ) on the microstructure, composition, and room-temperature tribological properties of the borided samples was investigated by X-ray diffraction, scanning electron microscopy, and ballon-disc tribometry, respectively. Gibbs free energy was also calculated to evaluate the compounds generated during the boriding at different temperatures. After a detailed analysis of the crystal structures and the growth morphologies of $\mathrm{TiB}$, the diffusion mechanisms for $\mathrm{B}$ atoms in $\mathrm{TiB}$ and $\mathrm{TiB}_{2}$ were discussed in the present report. The boriding temperature had a large effect on the microstructure, mechanical properties, and room-temperature tribological behavior of the borided samples, attributed to the changes in the composition and the increased hardened layer under elevated boriding temperature. The modeling of layer growth kinetics was also discussed in this paper. The actual value of hardened layer thickness was compared to the calculated value, and the difference was analyzed. The fricative value of the borided samples showed a minimum value of $88.9 \mathrm{~dB}$ for a boriding temperature of $1050{ }^{\circ} \mathrm{C}$. The depth and width of the wear tracks decreased gradually with increasing boriding temperature. The worn surface of the samples borided at higher temperatures showed very good wear resistance. A boriding condition of $1050{ }^{\circ} \mathrm{C}$ was considered optimal, as it provided sufficiently high surface hardness and a low fricative value to reduce vibrations during practical use.
\end{abstract}

Keywords: boriding; titanium; layer growth kinetics; mechanical properties; tribological properties; fricative reduction properties

\section{Introduction}

With the development of socioeconomic and environmental protection requirements, materials science and technology play a special role in increasing production and energy efficiency in a range of industrial fields. Among mechanical materials, titanium and its alloys exhibit excellent specific strength, biocompatibility, and corrosion resistance, and are widely used in automobile engines, heart stents, shells of electronic devices, etc. [1]. Further improvements in the surface properties of $\mathrm{Ti}$ are required to enable its use in a wider range of applications. To address this challenge, a series of surface modification techniques have been developed [2]. Although titanium has greater affinity for oxygen, it is prone to oxidation, which can serve the purpose of resisting corrosion. However, the resulting protective film is relatively thin, and when the surface film is broken, the corrosion resistance will instantly decrease [3]. Recently, effective surface modification techniques, such as deposition and diffusion, have been adopted [4,5]. The deposition method mainly included physical vapor deposition (PVD) and chemical vapor deposition (CVD). In addition, the diffusion method mainly refers to the method of diffusing another element in the metal to improve the mechanical properties. For example, carburizing, nitriding, 
boriding, and so on. Those methods have been shown to increase the abrasive resistance and extend the service life of Ti parts, which reduces the waste of natural resources.

In general, a uniform and continuous hardened compound layer formed on the surface of a material is beneficial to increase the abrasive resistance of mechanical parts. Boriding techniques are widely used in industry, as they can produce a modified layer with moderate thickness and high bonding strength via a simple process $[6,7]$. The $\mathrm{TiB}_{2}$ surface layer of pure titanium obtained by boriding not only has high hardness and good wear resistance, but also has good thermal conductivity. In addition, boriding is the process of infiltrating boron atoms into the metal surface to obtain one or more intermetallic compounds. Due to its convenient operation, the treated samples have high hardness and good wear resistance to be applied widely. Based on this, some studies demonstrated that Ti can be modified by boriding; many methods are commonly used to enhance the surface hardness of Ti, such as dissolved salt impregnation, electrolytic boriding, heat treatment, and magnetron sputtering [8-13]. During these methods, there are few reports of boriding by dissolved salt impregnation, especially with regard to the actual value of diffusion compared to the calculated value.

Many preliminary studies of boriding pure Ti have been performed, but few investigated different boriding temperatures [14-18]. Kara et al. reported that boriding titanium at $950{ }^{\circ} \mathrm{C}$ substantially increases its wear resistance. Additionally, at this processing temperature, surface hardness achieved the maximum value [14]. Duan Y. H. et al. reported the growth kinetics of Ti-6Al-4V alloy by boriding. It was found that the growth of boride layers is controlled by B diffusion [19]. Ma L. S. et al. researched the microstructure on grade- 2 pure Ti by molten salt boriding. It was found that the boride layers are mainly composed of $\mathrm{TiB}$ whiskers and $\mathrm{TiB}_{2}$ layers [20]. Kong Y. Y. et al. have also reported the properties of the layer of boriding and found that the thickness of the layer of boriding increases and the tribological properties improve with increasing boriding time [21]. In previous studies, boriding mixtures containing a boron source, an activator, and a filler material were used at high temperatures to achieve a thick monolithic layer on the titanium surface [22]. Therefore, further investigation found that if we want to achieve a durable surface layer and optimize the layer properties, we need a sample that has been borided under various conditions. In addition, the research of $\mathrm{B}$ diffusion rate in $\mathrm{TiB}$ and $\mathrm{TiB}_{2}$ of pure titanium is also important.

Among the surface modification methods mentioned above, dissolved salt impregnation is the simplest and most commonly used boriding method, which is convenient for industrial production. The $\mathrm{TiB}_{2}$ surface layer produced during Ti boriding has high hardness, high wear resistance, low resistivity, and high thermal conductivity [22]. In this process, the Ti specimen is immersed in a molten salt containing boric acid and aluminum, and boriding occurs at high temperatures [23]. The aluminum in the salt bath is a reducing agent for the boron oxide, which is impregnated into the surface of the Ti substrate [23]. This method can also prepare a band-shaped boride layer, composed of $\mathrm{TiB}_{2}$ and $\mathrm{TiB}$, and surface hardness can reach about $1500 \mathrm{HV}$ [24].

However, the use of dissolved salt impregnation for hardening pure Ti and the relationship between mechanical properties and the treating process have not yet been studied in detail. In addition, there is little research on the principle of formation and diffusion of the hardened layer by boriding with different processing temperatures. In this research, the diffusion rate of $\mathrm{B}$ in $\mathrm{TiB}$ and $\mathrm{TiB}_{2}$ is discussed. In addition, growth morphology (TiB), B diffusion coefficient, and diffusion mechanism were researched. Regarding wear depth, the difference between the measured value and the calculated value was analyzed to research the wear amount of the friction pair.

The aim of this study was to synthesize a continuous thick boride layer on grade- 2 pure Ti by boriding in a furnace using the molten salt impregnation method. The effects of the heat-treatment condition (boriding temperature) on the formation, microstructure, and mechanical and tribological properties of the borided layer were investigated. In the present study, no additive agent was used to accelerate the boron diffusion process because 
the additive agent may hinder the diffusion of boron atoms through the surface layer to the Ti substrate. To understand the development of the borided layer, the Gibbs free energy of possible boriding reactions with titanium was calculated using the NIST-JANAF thermochemical tables. The actual value of hardened layer thickness was compared to the calculated value to study the formation of the hardened layer. The borided layer formed on the grade- 2 pure Ti surface provided a protective coating against serious wear loss during the service period. Therefore, the correlations between boriding temperature and properties, including the fricative value, are discussed in this research. The actual value of wear depth was compared to the calculated value, and the form of wear was analyzed and studied in detail.

\section{Materials and Methods}

\subsection{The Processing Steps of Samples}

Grade-2 pure Ti (composition in wt.\%: $0.2 \mathrm{O}, 0.003 \mathrm{~N}, 0.013 \mathrm{H}, 0.25 \mathrm{Fe}, 0.008 \mathrm{C}$, and remainder Ti) was used as the substrate material. A substrate sample of $50 \times 20 \times 5 \mathrm{~mm}$ was cut from the newly received plate using fine-cut machining (Heiwa Technica, HS$45 \mathrm{~A} 2$ ), and then mechanically polished to a surface finish of 4000-grain size to remove the thick oxide layer on the surface. The size of the sample is shown in Figure 1. In addition, the composition and mechanical properties of grade- 2 pure Ti are shown in Table 1. The required surface roughness was obtained to make it easy for the boron atoms to react with the substrate while facilitating the evaluation of wear properties. The boriding experiments were performed in a molten solution under elevated temperature, and the agent was premixed $100 \mathrm{~g}$ aluminum $(99.9 \%$ purity) and $1000 \mathrm{~g}$ sodium tetraborate $\left(\mathrm{Na}_{2} \mathrm{~B}_{4} \mathrm{O}_{7}\right)$. Boriding was performed at $950{ }^{\circ} \mathrm{C}, 1050{ }^{\circ} \mathrm{C}$, or $1150{ }^{\circ} \mathrm{C}$ for $7200 \mathrm{~s}$ in a crucible. In addition, the processing parameters of the grade- 2 pure Ti are shown in Table 2. Then, the samples were cooled to room temperature $\left(25^{\circ} \mathrm{C}\right)$ in water, followed by boiling the samples in water for $1800 \mathrm{~s}$ to remove the remaining surface deposits.

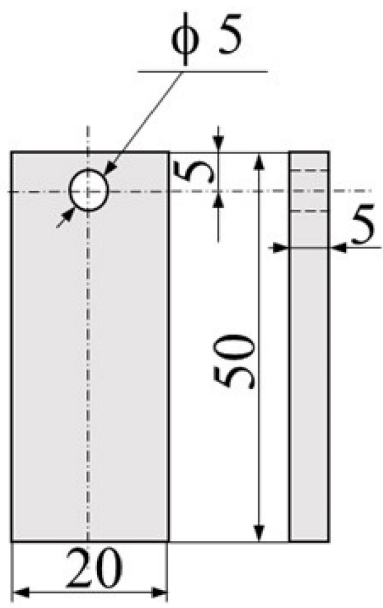

Figure 1. Schematic illustration of to-be-processed specimen (in mm).

Table 1. Composition and mechanical properties of grade-2 pure Ti.

\begin{tabular}{|c|c|c|c|c|c|c|c|c|c|}
\hline \multicolumn{6}{|c|}{ Elements (Mass\%) } & \multirow{2}{*}{$\begin{array}{c}\text { Tensile } \\
\text { Strength/MPa }\end{array}$} & \multirow{2}{*}{$\begin{array}{c}\text { Yield } \\
\text { Strength/MPa }\end{array}$} & \multirow{2}{*}{ Elongation/\% } & \multirow{2}{*}{$\begin{array}{l}\text { Phase Transition } \\
\text { Temperature } /{ }^{\circ} \mathrm{C}\end{array}$} \\
\hline $\mathrm{C}$ & $\mathbf{H}$ & $\mathrm{O}$ & $\mathbf{N}$ & $\mathrm{Fe}$ & $\mathrm{Ti}$ & & & & \\
\hline$\leqq 0.01$ & $\leqq 0.002$ & $\leqq 0.03$ & $\leqq 0.01$ & $\leqq 0.03$ & Bal. & 302 & 233 & 44 & $884 \pm 2{ }^{\circ} \mathrm{C}$ \\
\hline
\end{tabular}


Table 2. Processing parameters of the grade-2 pure Ti.

\begin{tabular}{cc}
\hline Processing Temperature $/{ }^{\circ} \mathbf{C}$ & Processing Time $/ \mathbf{h}$ \\
\hline 950 & 2 \\
1050 & 2 \\
1150 & 2 \\
\hline
\end{tabular}

\subsection{Structural and Mechanical Properties}

The microstructure of the compounds generated in this study was analyzed using $\mathrm{X}$-ray diffraction (XRD; Rigaku, $2200 \mathrm{VF}$ ) with a $\mathrm{Cu} \mathrm{K} \alpha$ radiation source operated at a voltage of $32 \mathrm{kV}$ and current of $20 \mathrm{~mA}$. The scanning speed and range were $4^{\circ} \mathrm{min}^{-1}$ and $5-90^{\circ}$, respectively. The cross-sections of borided samples were prepared by ion milling (Hitachi, IM4000) for $7200 \mathrm{~s}$. The microstructure and morphological characteristics of the borided layer were detected using a scanning electron microscope (SEM; Shimadzu, SSX550). The elemental distribution of the cross-sectional samples was determined by energy dispersive spectroscopy on an energy dispersive analyzer (EDX; Shimadzu, SEDX-500). Hardness measurements were performed on the untreated and treated samples using a Vicker hardness tester (Shimadzu, HMV-1) with different applied loads (0.49 and $0.98 \mathrm{~N}$ with a dwell time of $15 \mathrm{~s}$ ) to accurately measure the hardness, each sample was tested from the lower part of the sample to the upper part for 5 points, with an interval of $2 \mathrm{~mm}$ between each point (see Figure 1).

\subsection{Tribological Properties}

Ball-on-disc dry sliding tests were carried out at room temperature to evaluate the tribological properties of the samples using a tribometer (Rhesca, FPR-2000) with a zirconium dioxide $\left(\mathrm{ZrO}_{2}\right)$ ball and a counter-face with a radius of $2380 \mu \mathrm{m}$. The device appearance of the wear testing using in this research is shown in Figure 2. Samples with dimensions of $50 \times 20 \times 5 \mathrm{~mm}$ were used for wear testing with a sliding linear speed of $200 \mathrm{~mm} / \mathrm{s}$, an applied force (loading force during the wear testing) of $4.9 \mathrm{~N}$, and a test time of $3600 \mathrm{~s}$ (corresponding to a sliding distance of $720 \mathrm{~m}$ ). All tests were performed at room temperature. The microstructures of the treated sample surfaces were examined using SEM under secondary electron imaging mode at a voltage of $15 \mathrm{kV}$.

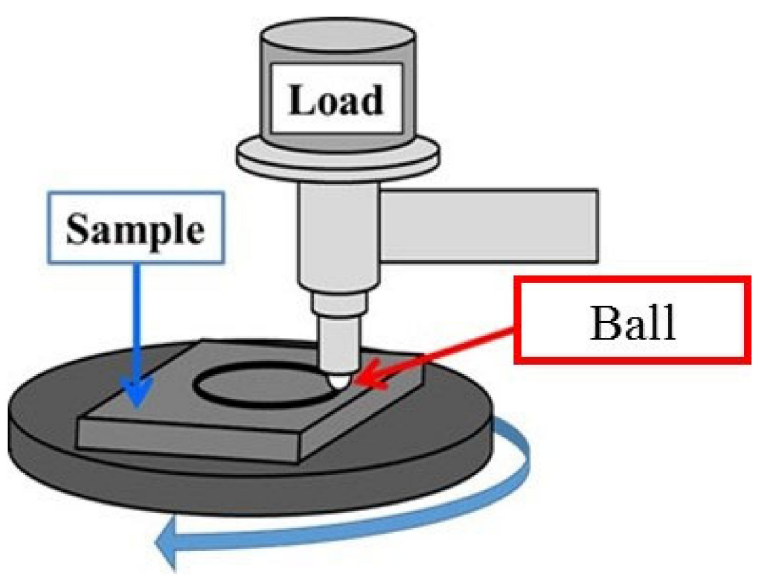

Figure 2. Schematic illustration of ball-on-disc dry sliding tester.

Wear depth was calculated using Equation (1) and assuming that the abrasion partner ball was not worn [25].

$$
d=r-\sqrt{r^{2}-\left(\frac{w}{2}\right)^{2}}
$$


Here, $r=2380 \mu \mathrm{m}$ (the radius of a grinding ball), and $d$ and $w$ are the measured values of wear depth and width, respectively. The specific variables of Equation (1) are shown in the Figure 3.

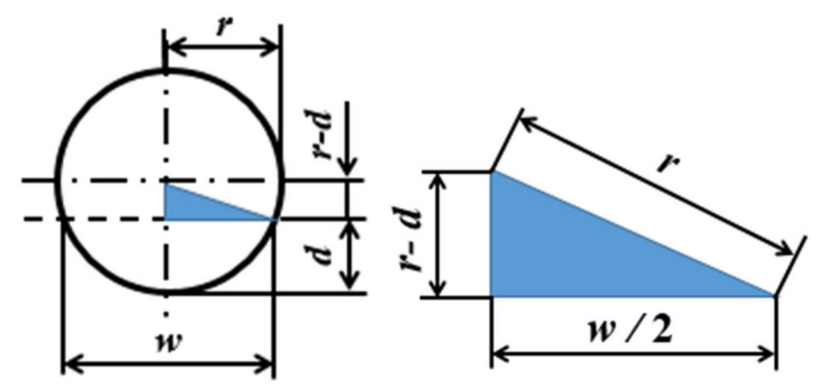

Figure 3. The specific variables of Equation (1).

As shown in Figure 4, the experimental device consisted of a pin plate that pushed a cantilever into the circumferential surface of a rotating thick steel plate. The fricative value was also called frictional noise and measured with a condenser microphone (Tenmars, TM-103) installed $20 \mathrm{~mm}$ above the contact point between the grinding ball and the sample surface. The condenser microphone had four selection modes for measuring the fricative value: A, C, FAST, and SLOW, which corresponded to the normal sound of materials, sound-absorbing materials, intermittent sound, or maximum fricative and the average fricative of materials, respectively. In this current study, since Ti is not a sound-absorbing material and we aimed to measure the fricative of this material over $3600 \mathrm{~s}$ to calculate the average value, the A and FAST modes were selected to measure the fricative of samples during wear testing.

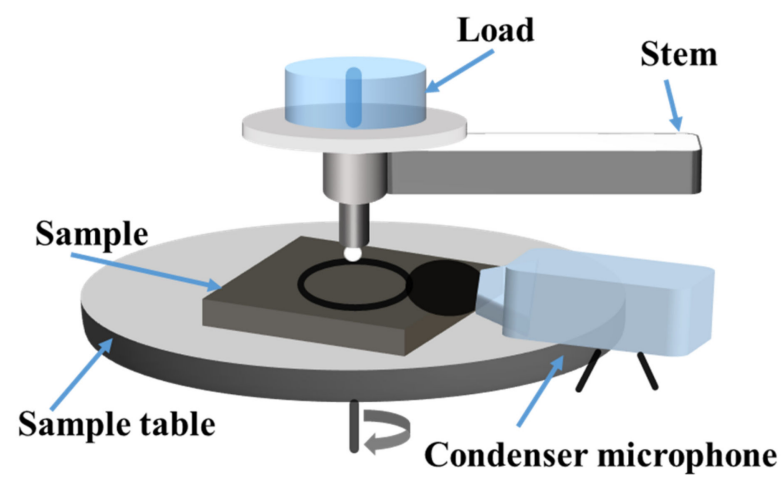

Figure 4. Experimental apparatus of wear and fricative testing.

\section{Results and Discussions}

\subsection{Composition and Microstructure}

The XRD analysis results of the treated samples at different boriding temperatures are shown in Figure 5. In all processing temperatures, the dominant diffraction peaks were assigned to the $\mathrm{TiB}_{2}$ phase and showed relatively higher intensity than those of the TiB phase. It resulted that the surface of the base sample formed a thick and dense layer of $\mathrm{TiB}_{2}$. Similar results have been reported in previous studies [14]. $\mathrm{TiB}_{2}$ was the dominant phase for the samples treated at all boriding temperatures. At lower boriding temperatures, a very thin boride layer composed of $\mathrm{TiB}_{2}$ and $\mathrm{TiB}$ was formed on the Ti surface. However, borided layer composition changes with increasing boriding temperature; Aich et al. [26] noted that under the same $\mathrm{XRD}$ analysis conditions, the thickness of the $\mathrm{TiB}_{2}$ layer increased with the processing temperature increasing. In addition, the TiB phase became undetectable. Here, a similar trend can be observed. 


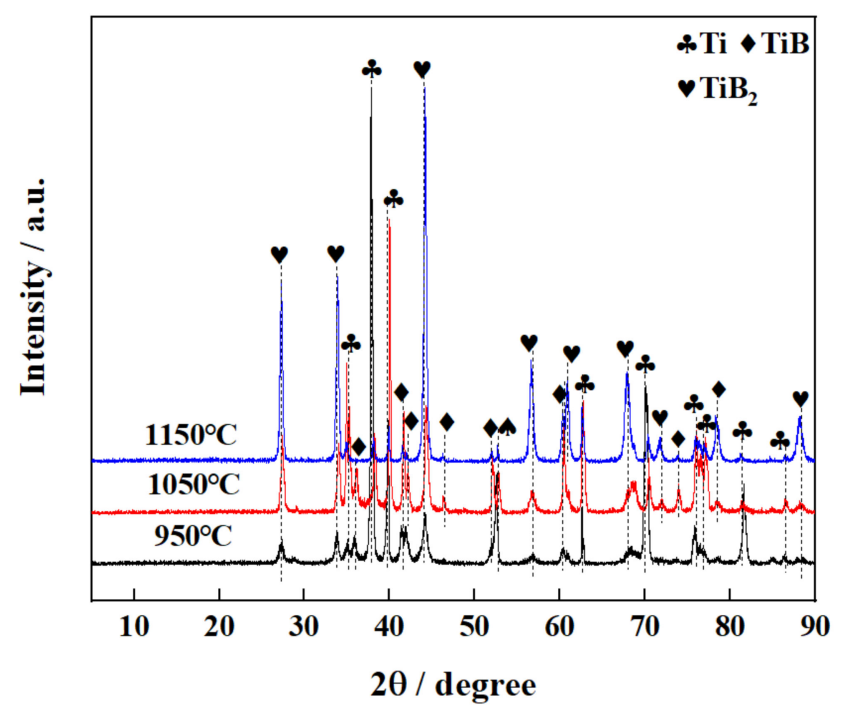

Figure 5. XRD patterns of the surface of specimens with different boriding temperatures.

Figure 6 shows the Gibbs free energy $(\Delta r G)$ profile of the boriding reaction in the temperature range from 300 to $2000{ }^{\circ} \mathrm{C}$ (see Equations (2)-(4) below), as calculated using the NIST-JANAF thermochemical numeric data [27]; the values corresponding to specific temperatures are listed in Table 1.

$$
\begin{gathered}
\mathrm{Ti}+2 \mathrm{~B} \rightarrow \mathrm{TiB}_{2} \\
\mathrm{Ti}+\mathrm{B} \rightarrow \mathrm{TiB} \\
\mathrm{Ti}+\mathrm{TiB}_{2} \rightarrow 2 \mathrm{TiB}
\end{gathered}
$$

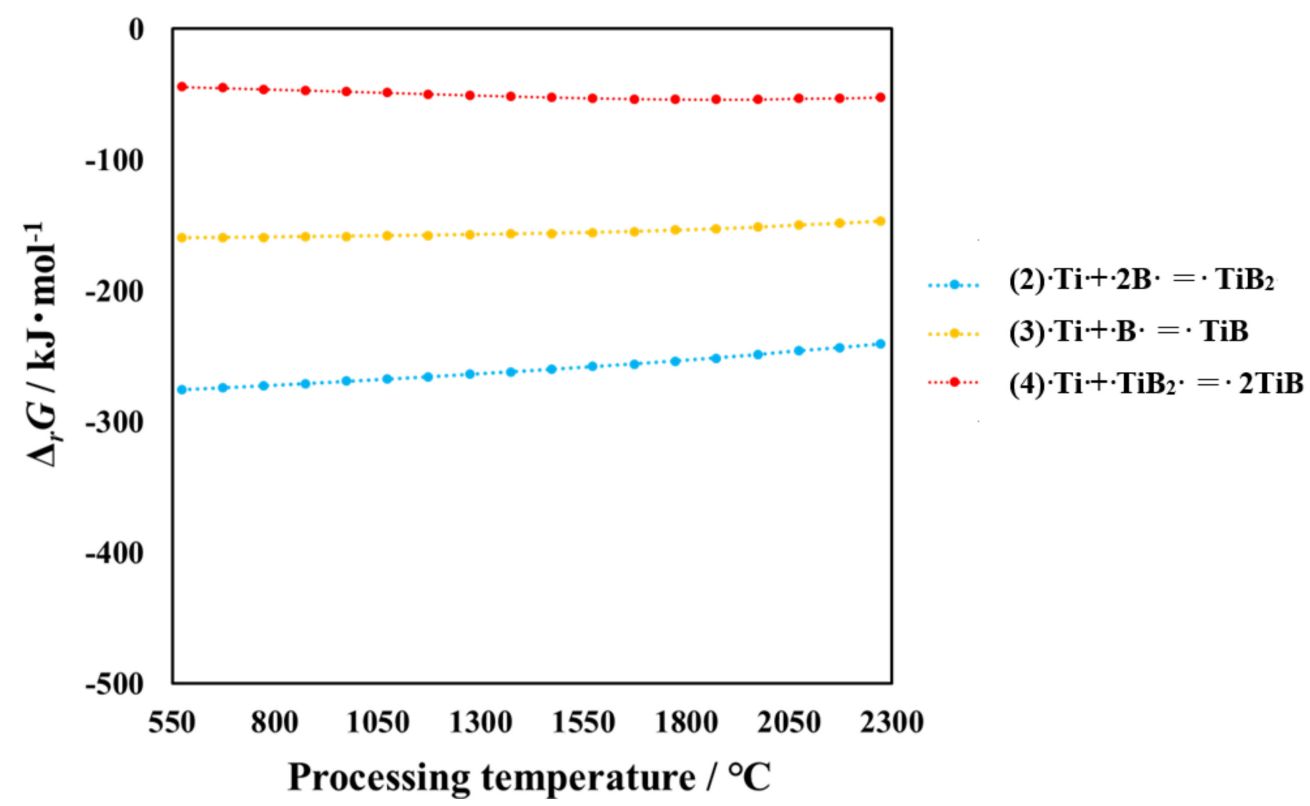

Figure 6. Gibbs free energy of B-Ti compounds with different boriding temperatures.

As is well-known, the reaction can only occur when the $\Delta r G$ is less than zero, and the smaller the $\Delta r G$, the easier the reaction occurs [28]. From Figure 6, the Gibbs free energy values of the boriding reactions were negative, which indicates that the borides' relative energy was lower than that of titanium and boron in the energy level distribution, and the borides could be formed with sufficient activation energy. Under the same conditions, 
when the value of free energy was larger, namely less negative, the reaction proceeded with more difficulty. Due to the lower Gibbs free energy required to form $\mathrm{TiB}_{2}$ compared to $\mathrm{TiB}, \mathrm{TiB}_{2}$ was preferentially produced at the same boriding temperature with sufficient $\mathrm{Ti}$ and B elements. As shown in Table 3, at higher temperatures, a lower Gibbs free energy for both $\mathrm{TiB}$ and $\mathrm{TiB}_{2}$ formation was required, and hence, they formed more easily. Therefore, for the same products, higher boron contents are expected for samples borided at higher temperatures. From the perspective of material analysis, it is necessary to calculate the thermodynamic parameters. Thermodynamic calculations were performed on pure titanium, and the simulation results showed the types of borides that may be generated during the boriding of pure titanium in this study. During the boriding process, boron atoms diffuse from the molten salt into the titanium lattice from the surface to the substrate and react with titanium. With increasing boriding time, the number of boron atoms on the surface is higher than that in the bulk of the sample. Hence, most of the reactions between boron atoms and Ti occur on the surface. In this case, the reaction shown in Equation (2) was more likely to occur than those shown in Equations (3) and (4), resulting in $\mathrm{TiB}_{2}$, rather than $\mathrm{TiB}$, being formed on the outermost surface of the Ti sample. This is consistent with the preferential formation of $\mathrm{TiB}_{2}$ detected by $\mathrm{XRD}$ at $1150{ }^{\circ} \mathrm{C}$. Beneath the continuous $\mathrm{TiB}_{2}$ layer, boron content was relatively low. At this condition, boron content dominates the boriding reaction. Under this condition, the Gibbs free energy of the reaction shown in Equations (3) and (4) was more negative than that of $1 / 2 \mathrm{Ti}+\mathrm{B} \rightarrow 1 / 2 \mathrm{TiB}_{2}$ (see Table 3 ) with the same boron content, which meant that boron affinity potential with titanium of $\mathrm{TiB}$ was larger than that of $\mathrm{TiB}_{2}$, indicating that $\mathrm{TiB}$ was more easily formed than $\mathrm{TiB}_{2}$ in the region with lower boron content in the bulk of the samples.

Table 3. Standard Gibbs free energy of the boronation reaction with different boriding temperatures (Under 1 mol boron content condition, the Gibbs free energy of the reaction can be defined as the boron affinity potential with titanium).

\begin{tabular}{ccccc}
\hline $\begin{array}{c}\text { Boriding } \\
\text { Temperature } /{ }^{\circ} \mathbf{C}\end{array}$ & $\mathbf{T i B}$ (Equation (3)) & $\mathbf{T i B}$ (Equation (4)) & $\mathbf{T i B}_{\mathbf{2}}$ & $\mathbf{1 / 2} \mathbf{T i B}_{\mathbf{2}}$ \\
\hline 950 & -157.952 & -38.151 & -265.922 & -132.961 \\
1050 & -157.685 & -37.241 & -264.478 & -132.239 \\
1150 & -157.418 & -36.331 & -263.034 & -131.517 \\
\hline
\end{tabular}

Figure 7 shows SEM micrographs and EDX line analysis results of cross-sections of the treated layer of the titanium substrates borided at different boriding temperatures. A light gray double-borided layer composed of monolithic $\mathrm{TiB}_{2}$ and needle-like $\mathrm{TiB}$ whiskers was observed under the surface. No lack of discontinuity and adhesion between the breaker layer and the substrate was observed. This shows that the whisker-like TiB firmly fixed the boride layer on the substrate. This dual layer with higher boron content at the surface was consistent with the thermodynamic results. Previous studies [29-33] showed that TiB has a B27 structure, which makes the growth rate of TiB along the [010] direction faster than along the other crystal directions. In the B27 structure, the zigzag B chain and the Ti channel without B are parallel to the [010] direction. Therefore, based on the periodic bond chain theory, TiB grows faster in the [010] direction than the other directions, such as [101] and [100], making TiB morphologically needle-like or whisker-like. $\mathrm{TiB}_{2}$ has a simple hexagonal structure with a graphite-like B layer perpendicular to the [001] direction, which indicates that the growth rate of $\mathrm{TiB}_{2}$ along the [001] direction is slower than that along the [100] or [010] direction. Therefore, the morphology of $\mathrm{TiB}_{2}$ is layered perpendicular to the [001] direction. From Figure 7, the thickness of the total borided layer $\left(\mathrm{TiB}+\mathrm{TiB}_{2}\right)$ produced at $1150{ }^{\circ} \mathrm{C}$ in this study was about $30 \mu \mathrm{m}$, which consisted of a $7.5 \mu \mathrm{m}$-thick continuous and smooth monolithic $\mathrm{TiB}_{2}$ layer, with the remainder consisting of TiB whiskers. 


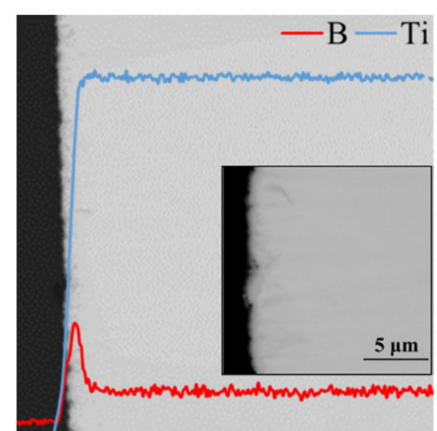

(a)

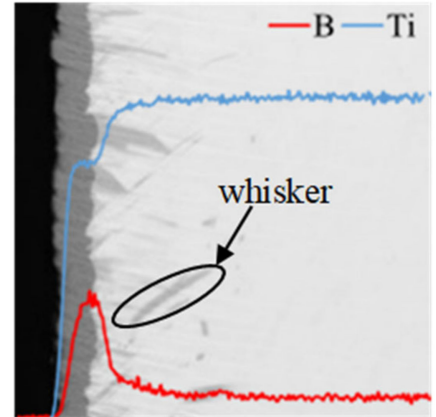

(b)

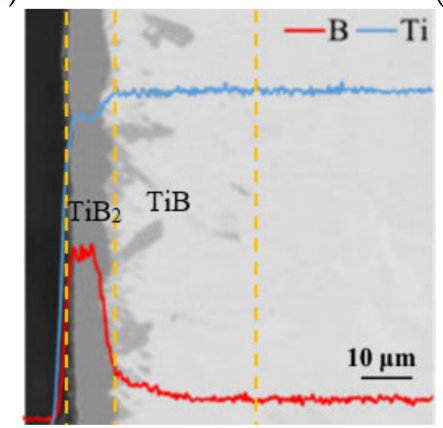

(c)

Figure 7. SEM images and EDX line analysis of cross-sections of samples with boriding temperatures of (a) $950{ }^{\circ} \mathrm{C}$, (b) $1050{ }^{\circ} \mathrm{C}$, and (c) $1150{ }^{\circ} \mathrm{C}$.

As the boriding temperature increased, the apparent improvement in the boriding of Ti was attributed to the composition and the content of the boriding mixture. The reactions producing $B$ atoms from sodium tetraborate and aluminum in the crucible are shown below.

$$
\begin{gathered}
\mathrm{Na}_{2} \mathrm{~B}_{4} \mathrm{O}_{7} \rightarrow 2 \mathrm{~B}_{2} \mathrm{O}_{3}+\mathrm{Na}_{2} \mathrm{O} \\
2 \mathrm{~B}_{2} \mathrm{O}_{3}+4 \mathrm{Al} \rightarrow 4 \mathrm{~B}+2 \mathrm{Al}_{2} \mathrm{O}_{3} \\
\mathrm{Na}_{2} \mathrm{~B}_{4} \mathrm{O}_{7}+4 \mathrm{Al} \rightarrow 4 \mathrm{~B}+2 \mathrm{Al}_{2} \mathrm{O}_{3}+\mathrm{Na}_{2} \mathrm{O}
\end{gathered}
$$

The TiB layer contained high-aspect-ratio whiskers inclined with respect to the substrate surface, some with a length of a few micrometers. Beneath this layer, we observed some discontinuous $\mathrm{TiB}$ particles, suggesting that some whiskers grew almost perpendicular to the surface (Figure 7). Additionally, comparing the SEM images of samples produced at $1050^{\circ} \mathrm{C}$ and $1150^{\circ} \mathrm{C}$ (Figure $7 \mathrm{~b}, \mathrm{c}$, respectively), it was found that the thickness of the $\mathrm{TiB}_{2}$ layers was similar. This is consistent with previous findings, where the thickness of the monolithic $\mathrm{TiB}_{2}$ layer increased while the thickness of the $\mathrm{TiB}$ whisker layer decreased with increasing boriding temperature above the phase transition temperature [34].

In addition, it can be seen from Figure 7 that the cross-sectional morphology of processing temperatures $950{ }^{\circ} \mathrm{C}$ and $1050{ }^{\circ} \mathrm{C}$ were different. Especially TiB had no obvious needle-like structure at this processing temperature. It may be due to the different diffusion rates of $\mathrm{B}$ in $\mathrm{TiB}_{2}$ and $\mathrm{TiB}$. The diffusion rate of $\mathrm{B}$ at the processing temperature of $950{ }^{\circ} \mathrm{C}$ was much lower than that at the processing temperature of $1050^{\circ} \mathrm{C}$. The specific calculation results are described later.

\subsection{Modeling of Layer Growth Kinetics}

Figure 8 shows the modeling of layer growth kinetics and the relative unit cells during the $\mathrm{B}$ atoms' diffusion into titanium. When $\mathrm{B}$ atoms diffuse into titanium, a $\mathrm{TiB}_{2}$ layer is formed on the surface first. $\mathrm{TiB}_{2}$ is a hexagonal crystal system, $\mathrm{C} 32$ structure, space group is $\mathrm{P} 6 / \mathrm{mmm}$, the number of molecules contained in the Bravais lattice unit cell is $\mathrm{M}=1$. The origin is at the center of symmetry, and the lattice constant at room temperature is 
$\mathrm{a}=0.304 \mathrm{~nm}, \mathrm{~b}=0.304 \mathrm{~nm}$, and $\mathrm{c}=0.322 \mathrm{~nm}$. The relative unit cell structure model of $\mathrm{TiB}_{2}$ is shown in Figure 8. As boriding time increases, $\mathrm{B}$ atoms diffuse to the inside to form a TiB layer. TiB is an orthorhombic crystal system, B27 structure, space group Pnma, the lattice constant at room temperature is $a=0.305 \mathrm{~nm}, \mathrm{~b}=0.456 \mathrm{~nm}$, and c $=0.612 \mathrm{~nm}$. The relative unit cell structure model of TiB is shown in Figure 6. The unit cell structure model of Ti has two types. When the boriding temperature is below phase transition temperature, $\mathrm{Ti}$ is $\alpha$ - Ti, space group is $\mathrm{P} 63 / \mathrm{mmc}$, and the lattice constant at room temperature is $\mathrm{a}=0.293 \mathrm{~nm}, \mathrm{~b}$ $=0.293 \mathrm{~nm}$, and $\mathrm{c}=0.466 \mathrm{~nm}$. When the boriding temperature is above phase transition temperature, $\mathrm{Ti}$ is $\beta$-Ti, space group is Im3-m, and the lattice constant is a $=0.282 \mathrm{~nm}$, $\mathrm{b}=0.282 \mathrm{~nm}, \mathrm{c}=0.282 \mathrm{~nm}$. Based on the results of the experiment, a uniform continuous $\mathrm{TiB}_{2}$ layer was formed on the surface, and active $\mathrm{B}$ atoms in the molten salt bath further diffused into the substrate through the $\mathrm{TiB}_{2}$ layer to form a needle-like TiB phase, which formed a two-phase composite sublayer structure with the remaining Ti substrate. The structure formation of the composite boride layer was determined by the thermodynamic and kinetic processes of the reaction of Ti and $\mathrm{B}$. The outermost layer was uniform and continuous, and the two sub-layers (TiB whisker layer + Ti substrate) maintained the borided layer structure in the crystallographic orientation relationship.

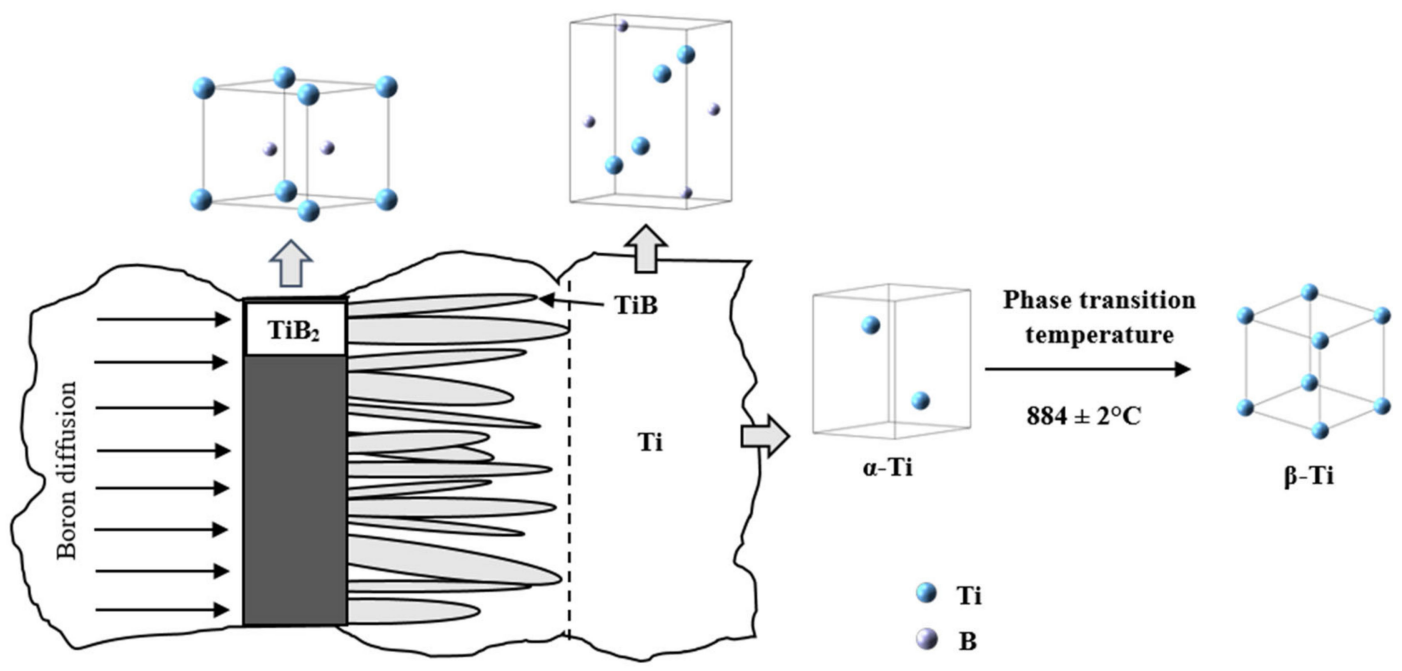

Figure 8. Schematic of growth of the hardened layer (the $\mathrm{TiB}_{2}$ outermost layer and the $\mathrm{TiB}$ whisker sublayer) and the unit cells corresponding to $\mathrm{TiB}_{2}, \mathrm{TiB}, \alpha-\mathrm{Ti}$, and $\beta-\mathrm{Ti}$, respectively.

Diffusivities of $B$ in $\mathrm{TiB}_{2}$ and $\mathrm{TiB}$ phases were determined from the research of $\mathrm{B}$. Sarma et al. [34]. In that study, the diffusivities of $\mathrm{B}$ in $\mathrm{TiB}_{2}$ and $\mathrm{TiB}$ were expressed with the following formula:

$$
D_{B}=D_{0} \exp \left(-\frac{Q}{R T}\right)
$$

$\mathrm{R}=8.314 \mathrm{~J} \cdot \mathrm{mol}^{-1} \cdot \mathrm{K}^{-1}$, where $Q$ and $D_{0}$ values for $\mathrm{B}$ diffusion in $\mathrm{TiB}_{2}$ are $187.1 \mathrm{~kJ}$ $\mathrm{mol}^{-1}$ and $6.8 \times 10^{-8} \mathrm{~m}^{2} \mathrm{~s}^{-1}$, respectively. The corresponding values in the TiB phase are $190.4 \mathrm{~kJ} \mathrm{~mol}^{-1}$ and $437.6 \times 10^{-8} \mathrm{~m}^{2} \mathrm{~s}^{-1}$, respectively. These values were determined from the research of B. Sarma et al. [34]. Table 4 presents the B diffusivities in the boride phases with different boriding temperatures used in the present calculations. As shown in Table 4, the diffusion rate of B became faster with the boriding temperature increasing. In addition, when the processing temperature was higher than $950^{\circ} \mathrm{C}$ (such as $1050^{\circ} \mathrm{C}$ and $1150{ }^{\circ} \mathrm{C}$ ), the diffusion rate of $\mathrm{B}$ in $\mathrm{TiB}$ and $\mathrm{TiB}_{2}$ was much higher than when the processing temperature was $950^{\circ} \mathrm{C}$. It is the reason why TiB had no obvious needle-like structure at this processing temperature. Comparing the diffusion rate of $\mathrm{B}$ in $\mathrm{TiB}$ and $\mathrm{TiB}_{2}$, it was found that the diffusion rate in $\mathrm{TiB}$ was higher than that in $\mathrm{TiB}_{2}$ at the same boriding 
temperature. Z. Fan et al. also found that the diffusion rate of B in TiB is higher than that in $\mathrm{TiB}_{2}$ [35]. That is the reason why a needle-like TiB layer is formed beneath the layer.

Table 4. Diffusivity data for various phases with different boriding temperatures.

\begin{tabular}{ccc}
\hline $\mathbf{T}\left({ }^{\circ} \mathbf{C}\right)$ & Diffusivity of $\mathbf{B}$ in $\mathbf{T i B}\left(\mathbf{m}^{2} / \mathbf{s}\right)$ & Diffusivity of $\mathbf{B}$ in $\mathbf{T i B}_{\mathbf{2}}\left(\mathrm{m}^{2} / \mathbf{s}\right)$ \\
\hline 950 & $3.23 \times 10^{-14}$ & $6.94 \times 10^{-16}$ \\
1050 & $1.33 \times 10^{-13}$ & $2.79 \times 10^{-15}$ \\
1150 & $4.48 \times 10^{-13}$ & $9.21 \times 10^{-15}$ \\
\hline
\end{tabular}

In order to study the acceleration kinetics of the growth of the boride layer near the transition temperature, in addition to knowing the diffusion rate of $B$ in the boride, the study of the diffusion rate of titanium in B is also necessary. However, due to the limited solid solubility of $\mathrm{B}$ in $\mathrm{Ti}$, and $\mathrm{Ti}$ and $\mathrm{B}$ easily reacting to form compounds, it is very difficult to measure the diffusion coefficient of B in the Ti substrate. This may be the reason why $\mathrm{B}$ diffusion data does not exist in the literature. Another question is whether B diffusion in the Ti phase occurs through interstitial or substitution mechanisms near the transition temperature. Assume that there is no interstitial diffusion of B in Ti. In addition, the higher concentration of substitution vacancies in the Ti substrate near the phase transition temperature can promote the increase of B diffusion through the substitution mechanism. In fact, previous studies have also shown [36] that the $\omega$ phase formed near the transition temperature may be a vacancy supersaturated phase, which tends to promote substitution diffusion near the phase transition temperature. Based on these, it can be reasonably assumed that B atoms diffuse through the substitution sites in Ti at a speed comparable to Ti itself.

As we all know, the growth of the interface reaction layer is a thermally activated process, and growth rate $(k)$ is closely related to temperature. This temperature dependence can be described by the following equation. The specific values are shown in Table 5 .

$$
k=k_{0} \exp \left(-\frac{Q^{k}}{2 R T}\right)
$$

where $k_{0}$ is a constant (a frequency factor), $Q_{k}$ is activation energy for layer growth, both $k_{0}$ and $Q_{k}$ are materials constants, $T$ is absolute temperature, and $R$ is the gas constant. These values were determined from the research of $Z$. Fan et al. [35]. It can be seen from Table 5 that the growth rate of $\mathrm{TiB}$ was higher than that of $\mathrm{TiB}_{2}$, which is consistent with the results observed in Figure 7 (the thickness of $\mathrm{TiB}$ was higher than that of $\mathrm{TiB}_{2}$ ). In addition, it was also found that the diffusion rate of $\mathrm{B}$ atoms in the TiB phase along the tip direction was more than 45 times that in the $\mathrm{TiB}_{2}$ phase. This result is the same as in the research of $\mathrm{M}$. Keddam et al. [37].

Table 5. Growth rates and the estimated diffusivity data for $\mathrm{B}$ in $\mathrm{TiB}$ and $\mathrm{TiB}_{2}$ with different boriding temperatures.

\begin{tabular}{cccccc}
\hline \multirow{2}{*}{$\mathbf{T}\left({ }^{\circ} \mathbf{C}\right)$} & \multicolumn{2}{c}{$\mathbf{k}\left(\times \mathbf{1 0}^{-\mathbf{4}}\right)\left(\mathbf{m} / \mathbf{s}^{\mathbf{1 / 2}}\right)$} & \multicolumn{2}{c}{$\mathbf{D}\left(\times \mathbf{1 0}^{-\mathbf{1 6}}\right) \mathbf{( \mathbf { m } / \mathbf { s } )}$} & \multirow{2}{*}{$\boldsymbol{D}_{\boldsymbol{B}}^{T i B} / \boldsymbol{D}_{\mathbf{B}}^{T i B_{2}}$} \\
\cline { 2 - 5 } & $\mathbf{T i B}$ & $\mathbf{T i B}_{\mathbf{2}}$ & $\mathbf{T i B}$ & $\mathbf{T i B}_{\mathbf{2}}$ & \\
\hline 950 & 14.73 & 2.34 & 322.7 & 6.94 & 46.5 \\
1050 & 29.88 & 4.70 & 1329 & 27.9 & 47.63 \\
1150 & 54.88 & 8.55 & 4485 & 92.1 & 48.7 \\
\hline
\end{tabular}

According to the results in Table 5, the diffusion distance was calculated from the diffusion coefficient using Equation (10). Note that $d$ is diffusion distance, $D$ is diffusion coefficient, and $t$ is processing time (it was $7200 \mathrm{~s}$ in this research).

$$
d=\sqrt{D t}
$$


According to the results in Table 6, the thickness of TiB was much greater than that of $\mathrm{TiB}_{2}$. This is consistent with the results observed in Figure 7. It can be seen from Table 6 that when the processing temperature is $1150{ }^{\circ} \mathrm{C}$, the thickness of $\mathrm{TiB}_{2}$ is about $8 \mu \mathrm{m}$, which is the same as the results actually observed in this research (Figure 7). However, at this processing temperature, the calculated thickness of $\mathrm{TiB}$ was much larger than the actual measured result (the thickness of TiB was about $22.5 \mu \mathrm{m}$ in this research). This was due to insufficient boron content. As we all know, TiB is formed by the reaction of $\mathrm{B}$ atoms obtained from $\mathrm{TiB}_{2}$. In this research, there were not enough boron atoms to react with titanium atoms, which led to the actual thickness of TiB being small. Namini A. S. et al. also found that the $\mathrm{B}$ atoms in $\mathrm{TiB}$ are obtained from $\mathrm{TiB}_{2}$, which makes $\mathrm{TiB}$ grow and $\mathrm{TiB}_{2}$ gradually become smaller [38].

Table 6. Diffusion calculation distance value with different boriding temperatures.

\begin{tabular}{ccc}
\hline \multirow{2}{*}{$\mathbf{T}\left({ }^{\circ} \mathbf{C}\right)$} & \multicolumn{2}{c}{$d(\times \mathbf{1 0}-\mathbf{6})(\mathbf{m})$} \\
\cline { 2 - 3 } & $\mathbf{T i B}$ & $\mathbf{T i B}_{\mathbf{2}}$ \\
\hline 950 & 15.2 & 2.24 \\
1050 & 30.9 & 4.48 \\
1150 & 56.8 & 8.14 \\
\hline
\end{tabular}

\subsection{Surface Vickers hardness}

Figure 9 shows the surface Vickers hardness of untreated and treated samples with different applied loads. The surface Vickers hardness of the untreated sample with applied loads of $0.49 \mathrm{~N}$ and $0.98 \mathrm{~N}$ was $335 \mathrm{HV}$ and $253 \mathrm{HV}$, respectively. With increasing boriding temperature, surface Vickers hardness increased to maximum values of $2767 \mathrm{HV}$ and $2340 \mathrm{HV}$ at $1150{ }^{\circ} \mathrm{C}$ for loads of $0.49 \mathrm{~N}$ and $0.98 \mathrm{~N}$, respectively. A previous study [39] showed that boriding of a Ti-6Al-4V alloy formed a layered structure mainly composed of $\mathrm{TiB}$ and $\mathrm{TiB}_{2}$, where the surface Vickers hardness of $\mathrm{TiB}$ was $2351-2757 \mathrm{HV}$, and that of $\mathrm{TiB}_{2}$ was about $3248 \mathrm{HV}$. The coexistence of $\mathrm{TiB}$ and $\mathrm{TiB}_{2}$ phases on the surface of the sample may lead to a lower surface Vickers hardness. Moreover, the surface Vickers hardness of our samples was lower than that of the hardness of the boride layers measured in the previous study. This was the result of the relatively thin boride layer on our samples, where the lower hardness of the base material also contributed to the measured surface Vickers hardness. This was evident from the surface Vickers hardness decreasing with increasing applied load; smaller loads resulted in smaller penetration depths and less contribution of the softer substrate material.

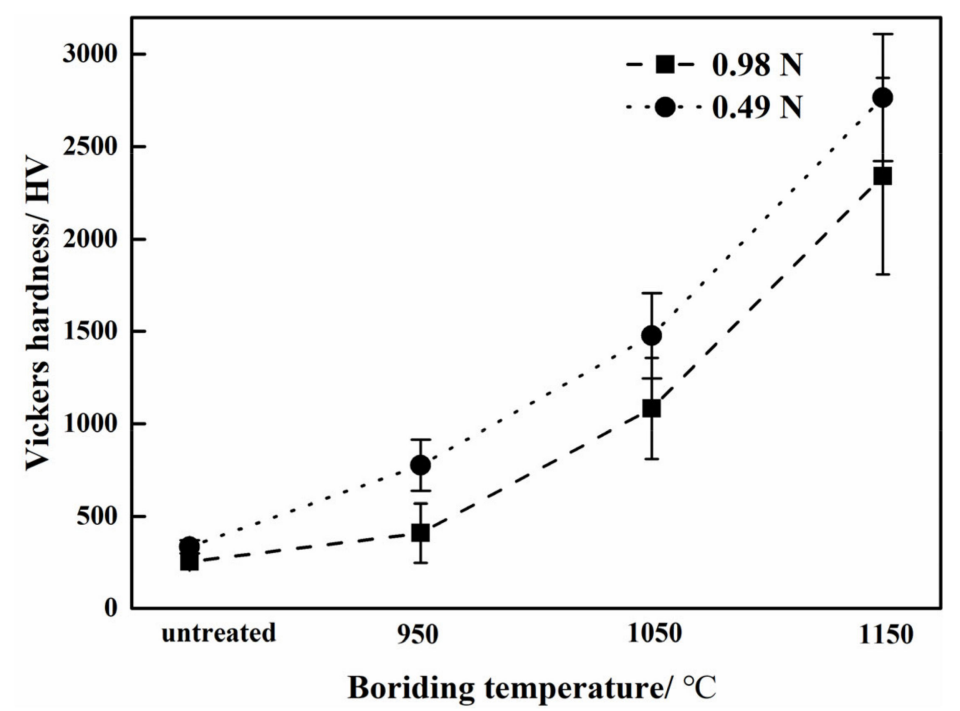

Figure 9. Surface Vickers hardness of samples with different boriding temperatures. 
The hardness of the surface layer is determined by a series of factors, including grain size distribution, phase composition, the thickness of the layer, and the crystallographic orientation between the strengthening phase and the substrate. Thicker hardened layers result in relatively higher measured hardness, as observed for the sample borided at $1150{ }^{\circ} \mathrm{C}$. At this processing temperature, the highest content and layer thickness of the hardest compound $\left(\mathrm{TiB}_{2}\right)$ were observed, resulting in the highest measured surface Vickers hardness for this sample. It is worth noting that the surface Vickers hardness testing results here show comprehensive performance of the hardened layer on the surface, not just the hardness of the borided layer, because the borided layer generated at lower processing temperatures was too thin for surface Vickers hardness testing. The test result was inevitably affected by the Ti substrate.

\subsection{Tribological Properties}

Figure 10 shows the trend of borided layer thickness and wear depth with different boriding temperatures after wear testing. As shown in Figure 10, with increasing boriding temperature, wear depth decreased, and thickness of the borided layer increased. It can be seen from Figure 10 that the wear depth of the treated sample was lower than that of the untreated sample. In addition, it was observed that the wear depth tended to decrease as the boriding temperature increased. It was due to the thickness of the hardened layer reducing the wear as the boriding temperature increased. The wear depth decreased gradually with the boriding temperature increasing. During the designed temperature range, when the boriding temperature increased to $1150{ }^{\circ} \mathrm{C}$, the wear depth reached the minimum value of $3.02 \mu \mathrm{m}$.

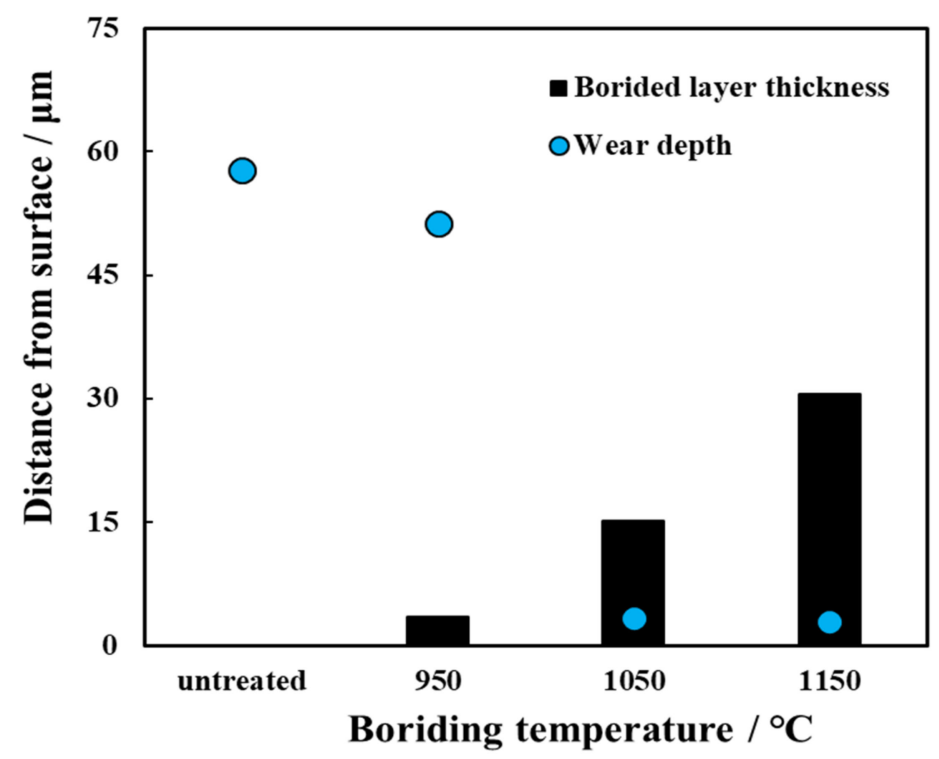

Figure 10. Trend of borided layer thickness and wear depth with different boriding temperatures after wear testing.

Figure 11 shows the corresponding SEM micrographs, EDX analysis, and 2D profilometric view of the worn surfaces of the untreated and borided samples after wear testing, from which the wear depth and width values were determined. Figure 11a shows evidence of severe plastic deformation with heavy smearing on the worn surface of the untreated sample due to repeated force applied to the sample surface during wear testing. The observed scratches and grooves indicate abrasion effects. From 2D profiles showing the wear depths, it is clearly seen that boriding of Ti substantially improved its wear resistance under a $4.9 \mathrm{~N}$ loading force. A wide and deep wear track formed on the untreated sample during wear testing. A continuous wear track with an average depth of $58 \mu \mathrm{m}$ and a width of $1240 \mu \mathrm{m}$ was formed on the untreated sample. The rough 2D wear track seen in the 
untreated sample was larger and deeper compared to those in the treated samples. It was due to severe plastic deformation with heavy smearing and scratches occuring on the surface of the untreated sample during wear testing.
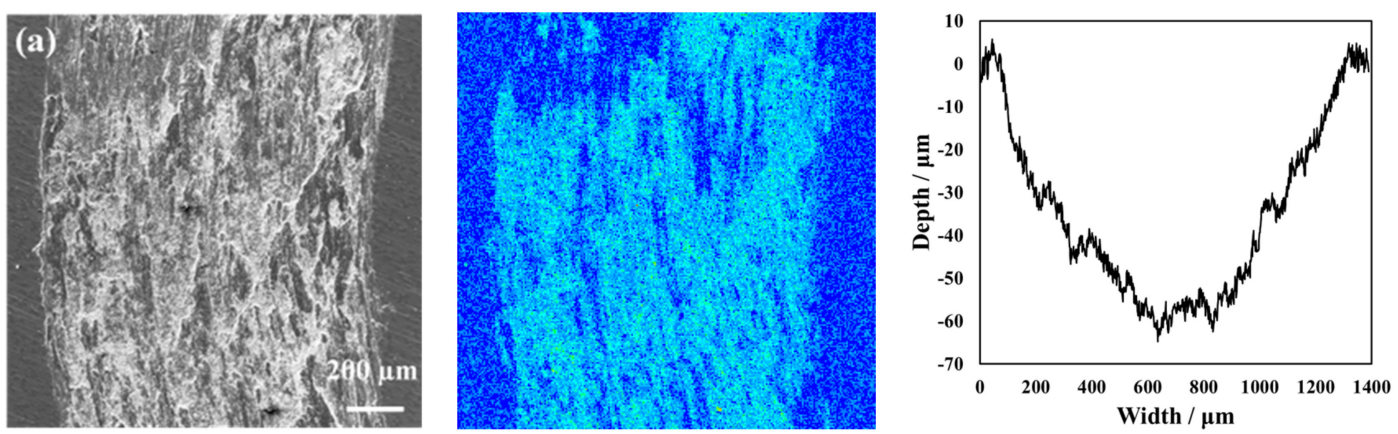

O
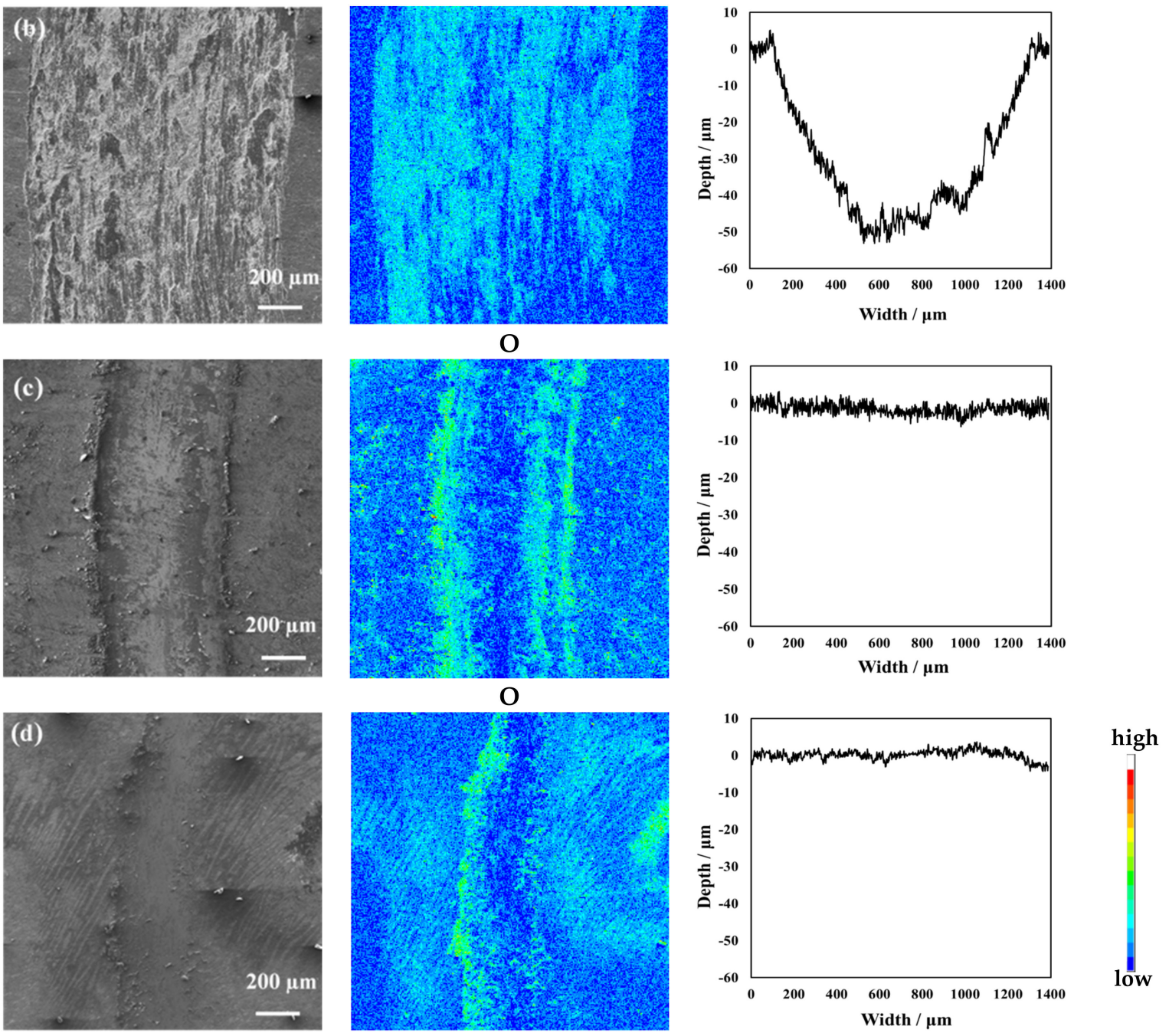

Figure 11. SEM micrographs, EDX analysis, and 2D profilometric view of the surfaces of the (a) untreated sample and those prepared using boriding temperatures of (b) $950{ }^{\circ} \mathrm{C}$, (c) $1050^{\circ} \mathrm{C}$, and (d) $1150{ }^{\circ} \mathrm{C}$, after wear testing.

The wear depth can be calculated with Equation (1) by supposing that an abrasion partner ball was not worn. The results are shown in Table 7. As shown in Table 7, it was found that the wear depths of the borided samples were smaller than that of the untreated sample. It was due to the formation of a boride layer on the surface. The boride layer has 
high hardness and acts as a protective Ti substrate during wearing with the grinding ball. In addition, Duan Yu. et al. also found that the wear of the treated sample by boriding is reduced [40]. The wear depth decreased gradually with increasing boriding temperature. Hence, the boriding of the pure Ti substrate substantially increased its wear resistance, consistent with the hardness measurements. The wear track of the sample borided at $950{ }^{\circ} \mathrm{C}$ was much deeper than those of the other borided samples, but slightly shallower than that of the untreated sample due to some increased hardening from the very thin boride layer. In this processing temperature, the binding force between the hardened layer and base material was low, and microparticles were removed from the surface during wear tests, producing the linear scratches observed in the wear scars (Figure 11b). At the boriding temperature of $1050{ }^{\circ} \mathrm{C}$, the worn surface showed limited deformation and smearing effects, and the wear depth was significantly smaller than in the untreated and $950{ }^{\circ} \mathrm{C}$ samples, attributed to the formation of a sufficiently thick hardened layer. Comparing the measured wear depth value of treated samples and the untreated sample, when the boriding temperature was $950{ }^{\circ} \mathrm{C}$, the wear track of the treated sample was relatively deeper, but lower than that of the untreated sample. This is attributed to the increased surface hardness enhancing wear resistance. The borided layer was very thin, the binding force at this processing temperature was low, and microparticles would be generated to increase wear loss. This consideration is supported by the fact that linear scratches were observed in the observation result of wear scars.

Table 7. Wear width and depth values of samples prepared using different boriding temperatures measured after wear testing (calculated wear depths are also given for comparison).

\begin{tabular}{cccc}
\hline \multirow{2}{*}{$\begin{array}{c}\text { Boriding } \\
\text { Temperature } /{ }^{\circ} \mathbf{C}\end{array}$} & Wear Width $/ \boldsymbol{\mu m}$ & Measured & Calculated \\
\cline { 3 - 4 } & & 58 & 82 \\
untreated & 1240 & 51 & 76 \\
950 & 1192 & 3.42 & 22 \\
1050 & 641 & 3.02 & 8.41 \\
1150 & 400 & & \\
\hline
\end{tabular}

When the boriding temperature increased to $1150{ }^{\circ} \mathrm{C}$, the worn surface of the treated Ti had no large-scale deformation and abrasion powder, and the wear marks were very narrow. It is estimated that the formation of the borided layer reduces the tendency of the adhesive to wear, resulting in very shallow and smooth wear marks. Samples have not been peeled or peeled off. The wear depth clearly decreased with increasing thickness of the hardened layers. The wear resistance of the treated samples was significantly improved due to the hard and adhesive layers formed during the boriding process (Figure 7). A hardened layer was achieved after boriding, containing a surface layer with ultra-high hardness with a slightly softer layer beneath. Such a surface layer is beneficial, especially for wearresistant materials, as it improves the adhesion and wear resistance of the soft titanium substrate. The softer TiB layer beneath the surface layer acts as damping and prevents delamination during wear, especially under heavy force. For the conditions studied in this research, the maximum boriding temperature of $1150{ }^{\circ} \mathrm{C}$ resulted in minimum wear width and depth values of $400 \mu \mathrm{m}$ and $3.02 \mu \mathrm{m}$, respectively. As shown in Table 7, the calculated wear depth values exceeded the measured ones. This suggests that the abrasion of the ball surface occurred in addition to the abrasion of the hardened layer, resulting in a transition from mechanical wear to abrasive wear. When the boriding temperature was $1050{ }^{\circ} \mathrm{C}$, the worn surface of the treated sample showed very limited deformation and smearing effects. As a result, the wear depth decreased significantly, which may be related to the sufficiently hardened layer being formed. Referring to Figures 7 and 10, it can be clearly seen that the wear depth was shallower when the hardened layer was thicker. This extraordinary improvement in wear resistance of the treated sample was attributed to the hard and adhesive subsurface layer formed during boriding (Figure 7). As pointed out above, a surface layer with ultra-high hardness was achieved on the outermost layer, 
with the substrate having gradually decreasing hardness. The hard surface layer increased both adhesive and abrasive wear resistance of the soft Ti substrate. The layer just below the outermost layer with relatively low hardness may have a good damping effect which prevents delamination during rubbing, especially under heavy loading conditions.

Although not clearly observed in the micrographs, it is well-known that oxidation readily occurs due to friction heating during wear testing because of the high affinity of Ti for oxygen. Therefore, we assume oxidative wear occurred in the samples at all boriding temperatures. The hardened layer can prevent the physical reaction of friction, thus reducing oxidation wear. The examination of the worn surface of the treated sample showed that there was no obvious plastic deformation, which was consistent with the extremely low wear rate. In addition, it can be seen from Figure 11 that some oxidative wear had occurred. This was due to the friction heat generated in wear testing, causing oxidation to occur. Stott F. et al. also got the same result [41].

The surface pressure calculated from the wear width after wear testing of the untreated sample and those borided at $950{ }^{\circ} \mathrm{C}, 1050{ }^{\circ} \mathrm{C}$, and $1150{ }^{\circ} \mathrm{C}$ were $0.41,0.44,1.52$, and $3.90 \mathrm{~N} / \mathrm{mm}^{2}$, respectively. The surface pressure of the untreated sample was lower than that of the borided samples, and the surface pressure increased with increasing boriding temperature. This was the reason why wear width decreased with increasing boriding temperature (corresponding to higher hardness values) for the same applied force. The surface pressure values of the $950{ }^{\circ} \mathrm{C}$ treating sample and the untreated sample were of the same order of magnitude, indicating similar wear severity. This was attributed to the very thin hardened layer formed at this low boriding temperature.

The different surface pressures observed for the samples prepared using different boriding temperatures are expected to affect the fricative values measured during the wear testing. Therefore, Figure 12 shows the fricative values as a function of time for all samples. With increasing wear testing time, the fricative value first increased and then decreased to a stable value. Over time, the actual contact area between the sample surface and the $\mathrm{ZrO}_{2}$ ball increase under fixed positive pressure, and the elastic deformation of the contact surface increases, resulting in an increase in the fricative value. When contact time is extended beyond a certain critical time, the elastic and plastic deformation of the contact surface no longer increases. With increasing contact time, the wear and plastic deformation of the contact point changes the surface morphology and the pressure state of the sample. After a certain time, the maximum dynamic friction force saturates and the wear enters a stable stage, resulting in a stable fricative value.

The average fricative values for the untreated sample and those borided at $950{ }^{\circ} \mathrm{C}$, $1050{ }^{\circ} \mathrm{C}$, and $1150{ }^{\circ} \mathrm{C}$ were $99.1,94.1,88.9$, and $93.2 \mathrm{~dB}$, respectively. The fricative value of the untreated sample was higher than those of the borided samples, indicating that boriding reduced the fricative value. The maximum fricative value was observed for the sample borided at $950{ }^{\circ} \mathrm{C}$, attributed to the thinner hardened layer that allowed the formation of particles via flaking, which wear with the sample and the grinding ball. The fricative value of the sample treated using a boriding temperature of $1050{ }^{\circ} \mathrm{C}$ was lower than that of the $1150{ }^{\circ} \mathrm{C}$ sample. The higher concentration of hard $\mathrm{TiB}_{2}$ in the $1150{ }^{\circ} \mathrm{C}$ sample (as confirmed by $\mathrm{XRD}$ ) resulted in lower elastic deformability during wear testing. Due to the high surface hardness of $\mathrm{TiB}_{2}$, the hardened layer was brittle. It was due to the surface hardness reaching the maximum value at this processing temperature. The higher the surface hardness, the easier the brittle fracture occurs. It was due to the weakening of the elastic deformation ability of the sample. Jahandari S. et al. also found that when the brittleness index is higher, elastic deformability is lower [42]. During wear testing, the sample deforms due to the absorption of mechanical energy. Brittle materials absorb less energy than soft ones during wear testing, resulting in larger vibrations and higher fricative values. The lowest fricative value was observed for the sample treated at a boriding temperature of $1050{ }^{\circ} \mathrm{C}$ due to the optimal ratio of $\mathrm{TiB}_{2}$ to $\mathrm{TiB}$. Hence, this material is considered suitable for practical use, as it will induce the least vibration under wear conditions. 


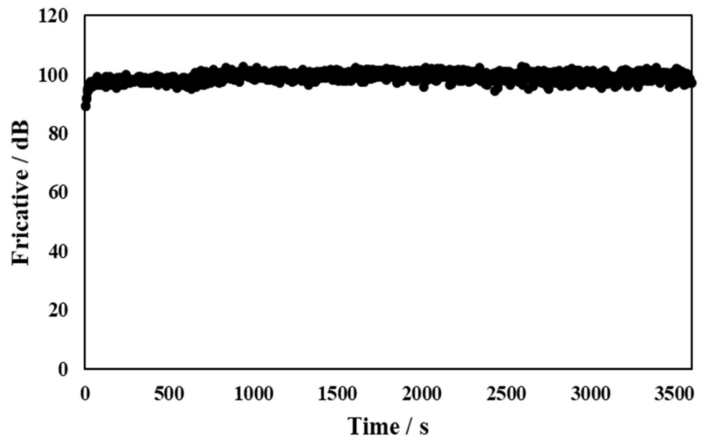

(a) untreated

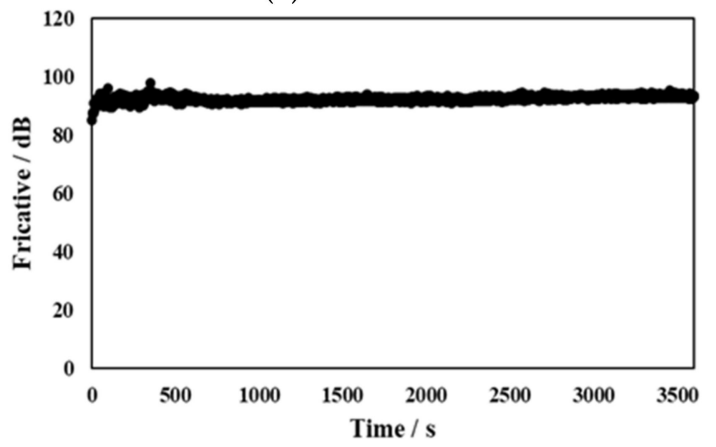

(c) $1050{ }^{\circ} \mathrm{C}$

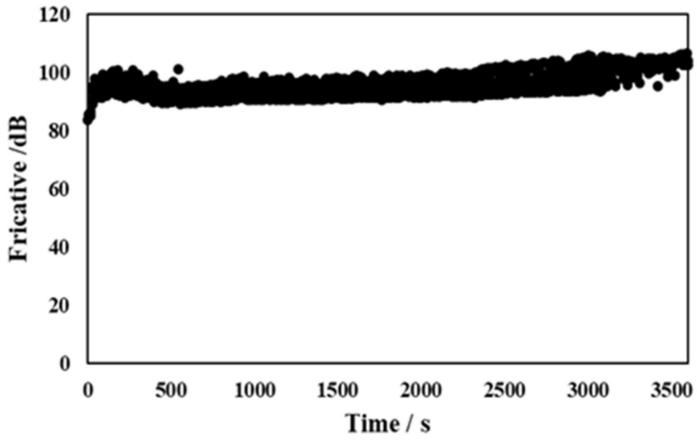

(b) $950^{\circ} \mathrm{C}$

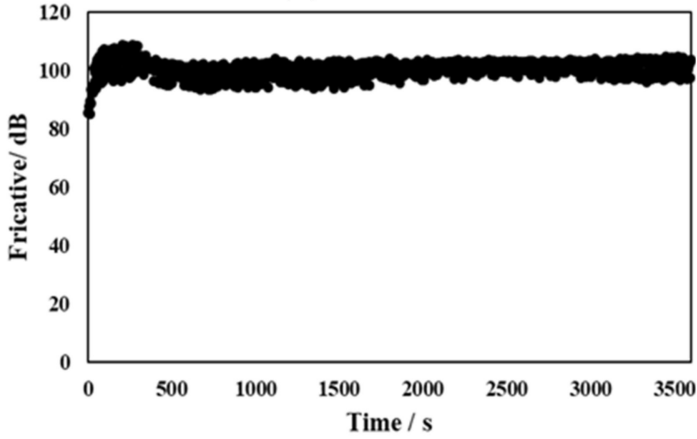

(d) $1150{ }^{\circ} \mathrm{C}$

Figure 12. Fricative value as a function of wear testing time for the (a) untreated sample and those prepared using boriding temperatures of (b) $950{ }^{\circ} \mathrm{C}$, (c) $1050{ }^{\circ} \mathrm{C}$, and (d) $1150{ }^{\circ} \mathrm{C}$.

\section{Conclusions}

The dissolved salt impregnation technique was used to investigate the effects of boriding temperature on the formation of boride layers on grade- 2 pure Ti. Detailed characterization of the structure, mechanical, and tribological properties yielded the following conclusions:

(1) Boriding at all tested processing temperatures resulted in the formation of a thick dual borided layer consisting of monolithic $\mathrm{TiB}_{2}$ and needle-like TiB whiskers, where the relative fractions of the two phases depended greatly on the boriding temperature.

(2) The introduction of $B$ into the Ti resulted in an initial increase in the thickness and surface hardness, with a maximum thickness of $30 \mu \mathrm{m}$ at a boriding temperature of $1150{ }^{\circ} \mathrm{C}$. As boriding temperature increased, increases in the surface hardness were observed for two different applied loads.

(3) Comparing the diffusion rate of $\mathrm{B}$ in $\mathrm{TiB}$ and $\mathrm{TiB}_{2}$, it was found that the diffusion rate in $\mathrm{TiB}$ was higher than that in $\mathrm{TiB}_{2}$ at the same boriding temperature. Additionally, the diffusion rate of $\mathrm{B}$ atoms in the TiB phase along the tip direction was more than 45 times that in the $\mathrm{TiB}_{2}$ phase.

(4) During the wear testing, the untreated sample surface had serious plastic deformation, stains, and scratches. The worn surfaces of the borided samples showed minor deformation and smearing effects at high boriding temperature, with minimum wear depth and width at a boriding temperature of $1150{ }^{\circ} \mathrm{C}$. The boriding process used in the present study substantially increased the wear resistance of Ti due to high surface hardness.

(5) The boriding treatment reduced the fricative value. As the boriding temperature increased, the fricative value of the samples decreased initially and then increased, with a minimum value of $88.9 \mathrm{~dB}$ at $1050^{\circ} \mathrm{C}$. 
Author Contributions: Conceptualization, T.C. and S.K.; methodology, S.K.; validation, T.C. and S.K.; formal analysis, T.C.; investigation, T.C.; resources, S.K. and L.Y.; data curation, T.C.; writingoriginal draft preparation, T.C.; writing-review and editing, S.K.; visualization, S.K.; supervision, L.Y. All authors have read and agreed to the published version of the manuscript.

Funding: This research received no external funding.

Institutional Review Board Statement: Not applicable.

Informed Consent Statement: Not applicable.

Acknowledgments: I am pleased to acknowledge experimental support by Shinji Koyama, Lihua Yu. This work was also supported by JATCO Ltd, thanks JATCO Ltd, the Functional Interface and Surface Fabrication laboratory at Gunma University, where the samples were produced and macroscopically compressed as part of a different research project.

Conflicts of Interest: No potential conflict of interest was reported by the authors.

\section{References}

1. Azar, G.T.P.; Ürgen, M. Effect of high-voltage pulse bias on the stress and morphology of CA-PVD TiN coatings. Surf. Eng. 2020, 36, 13-21. [CrossRef]

2. Jian, Y.X.; Huang, Z.F.; Xing, J.D.; Wang, Y. Investigation on two-body abrasive wear behavior and mechanism of Fe-3.0 wt $\%$ B cast alloy with different chromium content. Wear 2016, 362-363, 68-77. [CrossRef]

3. Fei, C.; Hai, Z.; Chen, C. Study on the tribological performance of ceramic coatings on titanium alloy surfaces obtained through microarc oxidation. Prog. Org. Coat. 2009, 64, 264-267. [CrossRef]

4. Mashreghi, A.R.; Soleimani, S.M.Y.; Saberifar, S. The investigation of wear and corrosion behavior of plasma nitrided DIN 1.2210 cold work tool steel. Mater. Des. 2013, 46, 532-538.

5. Nanesa, H.G.; Boulagkoff, J.; Jahazi, M. Influence of prior cold deformation on microstructure evolution of AISI D2 tool steel after hardening heat treatment. J. Manuf. Process. 2016, 22, 115-119. [CrossRef]

6. Kaestner, P.; Olfe, J.; Rie, K.T. Plasma-assisted boriding of pure titanium and TiAl6V4. Surf. Coat. Technol. 2001, 142-144, 248-252. [CrossRef]

7. Kartal, G.; Timur, S.; Urgen, M. Electrochemical boriding of titanium for improved mechanical properties. Surf. Coat. Technol. 2010, 204, 3935-3939. [CrossRef]

8. Chen, T.; Yu, L.H.; Xu, J. Influence of Ag content on the microstructure, mechanical, and tribological properties of TaVN-Ag films. Int. J. Miner. Metall. Mater. 2018, 25, 110-115. [CrossRef]

9. Zhu, Z.Y.; Cai, Y.F.; Gong, Y.J.; Shen, G.P.; Tu, Y.G.; Zhang, G.F. Isothermal oxidation behavior and mechanism of a nickel-based superalloy at $1000^{\circ} \mathrm{C}$. Int. J. Miner. Metall. Mater. 2017, 24, 776-783. [CrossRef]

10. Carrera-Espinoza, R.; Figueroa-Lopez, U.; Martinez-Trinidad, J. Tribological behavior of borided AISI 1018 steel under linear reciprocating sliding conditions. Wear 2016, 362-363, 1-7. [CrossRef]

11. Chen, T.; Yu, L.H.; Ju, H.B. Influence of $\mathrm{Cu}$ content on the microstructure, mechanical, and tribological properties of $\mathrm{ZrN}-\mathrm{Cu}$ films. Nano 2018, 13, 35-43. [CrossRef]

12. Asempah, I.; Yu, L.H.; Ju, H.B. Corrosion, oxidation and high-temperature tribological properties of Ti-B-N coatings. Surf. Eng. 2019, 35, 661-669. [CrossRef]

13. Asempah, I.; Xu, J.H.; Yu, L.H. Microstructure, mechanical and tribological properties of magnetron sputtered Ti-B-N films. Surf. Eng. 2019, 35, 701-709. [CrossRef]

14. Kara, G.; Pürcek, G.; Yanar, H. Improvement of wear behaviour of titanium by boriding. Ind. Lubr. Tribol. 2017, 69, 65-70. [CrossRef]

15. Kartal, G.; Timur, S. Growth kinetics of titanium borides produced by CRTD-Bor method. Surf. Coat. Technol. 2013, 215, 440-446. [CrossRef]

16. Zhou, F.M.; Zhang, H.X.; Sun, C.X. Microstructure and wear properties of multi ceramics reinforced metal-matrix composite coatings on Ti-6Al-4V alloy fabricated by laser surface alloying. Surf. Eng. 2019, 35, 683-691. [CrossRef]

17. Kulka, M.; Makuch, N.; Dziarski, P. Gradient boride layers formed by diffusion carburizing and laser boriding. Opt. Lasers. Eng. 2015, 67, 163-175. [CrossRef]

18. Li, X.L.; Yue, W.Y.; Huang, F. Tribological behaviour of textured titanium under abrasive wear. Surf. Eng. 2019, 35, 378-386. [CrossRef]

19. Duan, Y.; Li, P.; Chen, Z. Surface evolution and growth kinetics of Ti6Al4V alloy in pack boriding. J. Alloys Compd. 2018, 742, 690-701. [CrossRef]

20. Ma, L.S.; Duan, Y.H.; Li, P. Microstructure, Growth Kinetics and Some Mechanical Properties of Boride Layers Produced on Pure Titanium by Molten-Salt Boriding. J. Mater. Eng. Perform. 2017, 26, 4544-4555. [CrossRef]

21. Kong, Y.Y.; Sun, Y.; Duan, Y.H.; Peng, M.J. Preparation of boronized layer on pure titanium surface and its properties. Heat Treat. Met. 2017, 42, 148-152. 
22. Sarma, B.; Tikekar, N.M.; Chandran, K.S.R. Kinetics of growth of superhard boride layers during solid state diffusion of boron into titanium. Ceram. Int. 2012, 38, 6795-6805. [CrossRef]

23. Shackelford, J.F.; Alexander, W. CRC materials science and engineering handbook. Chem. Eng. 2000, 11, 40-41.

24. Huang, Y.G.; Chen, J.R.; Zhang, M.L. Electrolytic boronizing of titanium in Na2B4O7-20\% K2CO3. Mater. Manuf. Process. 2013, 28, 1310-1313. [CrossRef]

25. Anzawa, Y.; Koyama, S.; Shohji, I. The effect of boriding on wear resistance of cold work tool steel. J. Phys. Conf. Ser. 2017, 843, 1-5. [CrossRef]

26. Aich, S.; Chandran, K.S.R. TiB whisker coating on titanium surfaces by solid-state diffusion: Synthesis, microstructure, and mechanical properties. Metall. Mater. Trans. A 2002, 33, 3489-3498. [CrossRef]

27. Chase, M.W. NIST-JANAF Thermochemical Tables Fourth Edition. J. Phys. Chem. Ref. Data 1998, 4, 1-1950. [CrossRef]

28. Sun, Y.; Zhang, C.; Wu, J.; Meng, Q.; Liu, B.; Gao, K.; He, L. Enhancement of oxidation resistance via titanium boron carbide coatings on diamond particles. Diam. Relat. Mater. 2019, 92, 74-80. [CrossRef]

29. Wang, M.L. The investigation of dependences of mechanical and electronic properties of TiB2 on pressure using the first-principles method. Phys. Scripta 2014, 89, 115702. [CrossRef]

30. Chen, I.; Rosenflanz, A. A tough SiAlON ceramic based on a-Si3N4 with a whisker-like microstructure. Nature 1997, 389, 701-704. [CrossRef]

31. Li, Y.F.; Xu, H.; Xia, Q.L. First-principles calculation of structural and thermodynamic properties of titanium boride. J. Cent. South Univ. Technol. 2011, 18, 1773-1779. [CrossRef]

32. Wang, Q.; Liu, C.; Yao, R. First-principles study on the stability and work function of low-index surfaces of TiB2. Comp. Mater. Sci. 2020, 172, 109356. [CrossRef]

33. Chen, T.; Koyama, S. Influence of boriding temperature on microstructure and tribological properties of titanium. Solid State Sci. 2020, 107, 106369. [CrossRef]

34. Sarma, B.; Chandran, K.S.R. Accelerated kinetics of surface hardening by diffusion near phase transition temperature: Mechanism of growth of boride layers on titanium. Acta Mater. 2011, 59, 4216-4228. [CrossRef]

35. Fan, Z.; Guo, Z.X.; Cantor, B. The kinetics and mechanism of interfacial reaction in sigma fibre-reinforced Ti MMCs. Compos. Part A Appl. Sci. Manuf. 1997, 28, 131-140. [CrossRef]

36. Skotnikova, M.A. A crystallographic model of vacancy-supersaturation of the high-temperature b.c.c. modification of titanium. Met. Sci. Heat Treat. 1998, 40, 112-114. [CrossRef]

37. Keddam, M.; Taktak, S.; Tasgetiren, S. A diffusion model for the titanium borides on pure titanium. Surf. Eng. 2016, 11, 802-808. [CrossRef]

38. Namini, A.S.; Dilawary, S.A.A.; Motallebzadeh, A. Effect of TiB2 addition on the elevated temperature tribological behavior of spark plasma sintered Ti matrix composite. Compos. B Eng. 2019, 172, 271-280. [CrossRef]

39. Bosea, S.; Pathaka, L.C.; Singh, R. Response of boride coating on the Ti-6Al-4V alloy to corrosion and fretting corrosion behavior in Ringer's solution for bio-implant application. Appl. Surf. Sci. 2018, 433, 1158-1174. [CrossRef]

40. Duan, Y.; Wang, X.; Liu, D. Characteristics, wear and corrosion properties of borided pure titanium by pack boriding near $\alpha \rightarrow \beta$ phase transition temperature. Ceram. Int. 2020, 46, 16380-16387. [CrossRef]

41. Stott, F.H. The role of oxidation in the wear of alloys. Tribol. Int. 1998, 31, 61-71. [CrossRef]

42. Jahandari, S.; Li, J.; Saberian, M. Experimental study of the effects of geogrids on elasticity modulus, brittleness, strength, and stress-strain behavior of lime stabilized kaolinitic clay. GeoResJ 2017, 13, 49-58. [CrossRef] 